\title{
Genotype X Environment Interaction and Stability Analysis in Kenaf (Hibiscus cannabinus L.) for Growth and Yield Performances in Southwest Nigeria
}

\author{
O. N. Adeniyan ${ }^{1}$, O. A. Aluko ${ }^{1}$, S. O. Olanipekun ${ }^{1}$, J. O. Olasoji ${ }^{1}$, J. A. Adetumbi ${ }^{1}$, C. O. Alake ${ }^{2}$ \\ \& M. O. Adenekan ${ }^{3}$ \\ ${ }^{1}$ Institute of Agricultural Research and Training, Obafemi Awolowo University (OAU), Ibadan, Nigeria \\ ${ }^{2}$ Federal University of Agriculture, Abeokuta, Nigeria \\ ${ }^{3}$ Federal College of Agriculture, Ibadan, Nigeria \\ Correspondence: O. N. Adeniyan, Institute of Agricultural Research and Training, Obafemi Awolowo \\ University (OAU) P. M. B. 5029 Ibadan, Nigeria. Tel: 234-806-209-9747. E-mail: adeniyantayo@yahoo.com
}

Received: October 8, 2013 Accepted: December 5, 2013 Online Published: July 15, 2014

doi:10.5539/jas.v6n8p28 URL: http://dx.doi.org/10.5539/jas.v6n8p28

\begin{abstract}
Genotype $\mathrm{x}$ environment interaction and stability analysis for growth and yield performances of kenaf (Hibiscus cannabinus L.) were carried out by growing ten varieties of kenaf (a newly developed kenaf variety; Ife Ken DI 400 alongside with other two improved varieties developed in Nigeria, two exotic improved varieties, four lines and one local). The trials were conducted in the three research stations of the Institute of Agricultural Research and Training, Obafemi Awolowo University, Moor Plantation Ibadan. The research stations are located at Ikenne (high rain forest agro-ecology), Ibadan (transitional rain forest agro-ecology) and Ilora (derive savanna agro-ecology) in 2007 and 2008. Combined analysis of variance showed that there were significant $(\mathrm{P}<0.05)$ differences among the cultivars, locations, cultivar $\mathrm{x}$ year and year $\mathrm{x}$ location interactions for the traits investigated. Influence of year and cultivar $\mathrm{x}$ location and cultivar $\mathrm{x}$ location $\mathrm{x}$ year were not significant. There were significant differences in plant height, basal diameter, fiber yield and core yield among the cultivars, significant differences among locations in fiber yield and core yield and there were significant cultivar $\mathrm{x}$ year and year $\mathrm{x}$ location interactions for fiber yield and core yield. For stability analysis, the most stable cultivars in fiber yield and core yield were the improved varieties. For the fiber yield and core yield the most stable variety among the improved varieties was Ife Ken DI 400, followed by Ife Ken 400 and Ife Ken 100, while the fourth ranked stabled variety was Cuba 108. The most unstable improved variety was Tainung-1. Among the lines, AC 313-293 was most stable; it ranked seventh, while G 45-2 was regarded as most unstable cultivar followed by Local 35 and 2QQ $17^{4}$ that ranked eighth, ninth and tenth respectively.
\end{abstract}

Keywords: genotype, environment, interaction, yield, stability, kenaf, variety

\section{Introduction}

According to Dempsey (1975) and LeMahieu et al. (2003), kenaf (Hibiscus cannabinus L.) originated from sub-Saharan Africa. Commercially, kenaf has been successfully planted in many countries (FAO, 1998) in which Nigeria and South Africa are inclusive (Dempsey, 1975). Kenaf is commercially cultivated purposely for pulping and paper making, oil spills bioremediation, bio-degradable packaging materials and cordage materials (Cheng, 2001; Charles, 2002).

There are many strategies of improving kenaf production, one of these include breeding for early maturing, day length insensitive and pests and diseases resistant varieties. In plant breeding programme, information concerning the genetic diversity within crop species is essential for a reasonable use of genetic resources. According to Nel et al. (1998), three sources of variation in plant characteristics have been identified. These variation are thus, genotype $(\mathrm{G})$, environment $(\mathrm{E})$ and their interaction $(\mathrm{G} \times \mathrm{E})$. The major objectives of plant breeding as stated by Nasser and Huehn (1987) and Ceccarelli (1989) are basically for enhanced productivity in relation to a wider environment and biotic and abiotic factors for crop development. Fehr, (1991), Gauch and Zobel, (1997) reported that successful cultivars need to possess high performance for yield and other essential agronomics. Furthermore, they stated that their superiority should be reliable of a wide range of environmental 
conditions. The basic understanding of principles of genotype $\mathrm{x}$ environment interaction reduced the expense to be incurred on extensive genotype evaluation because it brings about elimination of unnecessary testing sites (Magari, 1996). The significance of such interactions between genotype and environment has been reported elsewhere by several workers for yield and yield components in kenaf (Ramagosa \& Fox, 1993; Basford \& Cooper, 1998; Baker, 1988; Jackson et al., 1998; Purchase, 1997).

Lin et al. (1986) and DeLacy et al. (1996) have indicated the different concepts and definitions of stability. There are two types of stability; static and dynamic (Becker \& Leon, 1988). According to them, stable genotypes have characteristics of unchanged or constant performances regardless of any variation of environmental factors. However, they described that dynamic allows a predictable response to environment. Ceccarelli (1989) has stated that farmers are interested in a constantly superior performance of cultivars on their own farms, specially adapted to their conditions and needs, and which have a high degree of stability over time.

Therefore, the purpose of this study was to determine the effect of environment on performance of a newly developed kenaf variety alongside with other two improved indigenous varieties, two exotic improved varieties, four lines and one local and to test the stability of the genotypes to the various environments where they are intended for cultivation.

\section{Materials and Methods}

In search of new kenaf varieties to be added to the varietal portfolio of kenaf farmers in Nigeria, hence, a new variety; Ife Ken DI 400 alongside with other two improved varieties developed by the Institute of Agricultural Research and Training, Obafemi Awolowo University, Moor Plantation Ibadan, two exotic improved varieties, four lines and one local (Table 1). The trials were conducted in three research stations of the Institute of Agricultural Research and Training, Obafemi Awolowo University, Moor Plantation Ibadan. The research stations are located at Ikenne; high rain forest agro-ecology $\left(6.87^{\circ} \mathrm{N}, 3.72^{\circ} \mathrm{E}\right)$, Ibadan; transitional rain forest agro-ecology $\left(7.39^{\circ} \mathrm{N}, 3.92^{\circ} \mathrm{E}\right)$ and Ilora; derive savanna agro-ecology $\left(7.82^{\circ} \mathrm{N}, 3.91^{\circ} \mathrm{E}\right)$ in 2007 and 2008 . The experimental design adopted was a randomized complete block and in each location, each plot was $1.5 \mathrm{x} 9 \mathrm{~m}$ with six rows of plant. The inter- and intra row spacing was $25 \mathrm{~cm}$ and $10 \mathrm{~cm}$ respectively. Ten cultivars of kenaf (one newly developed; Ife Ken DI 400, other two improved varieties; Ife Ken 400 and Ife Ken 100, two exotic improved varieties; Tainung-1 and Cuba 108, four lines; AC 313-293, 2QQ 174, S 72-78-10 and G 45-2 and one local variety; Local 35) seeds were sown mid April in different years of experimentation. Recommended doses of insecticides and fertilizer (N-P-K $=40-50-20 \mathrm{~kg} / \mathrm{ha}$ ) were applied and standard cultural practices were followed. At 50\% flowering, the plants were manually harvested for fiber and core yield. From each plot, four rows in the middle were harvested. To eliminate side-row effects, $1 \mathrm{~m}$ at both sides of these rows was discarded. This reduced the final plot size to $7 \mathrm{~m}^{2}$. Randomly, ten plants were selected from each plot and the following characteristics were measured and the mean per plot were calculated; plant height, basal diameter, fiber yield and core yield. The data collected were statistically analyzed using analysis of variance procedure. Means were compared using Duncan multiple range test at $5 \%$ level of probability. Stability analysis was performed using stability variance $\left(\mathrm{Q}^{2} \mathrm{i}\right)$ measure (Shukla, 1972).

\section{Results and Discussion}

\subsection{Separate Mean Values From Analysis of the Trials for the Three Locations in 2010 and 2011}

Mean values for four traits of the kenaf cultivars across three locations; Ikenne, Ibadan and Ilora in 2010 and 2011 seasons were shown in Tables 2 and 3. They indicated that fiber yield and core yield in Ilora (derive savanna agro-ecology) were obviously higher than Ikenne (high rain forest agro-ecology) and Ibadan (transitional rain forest agro-ecology).

\subsubsection{Plant Height}

Among the improved varieties, Ife Ken DI 400, Ife Ken 400, Tainung-1, Cuba 108 and Ife Ken 100 gave the significantly highest plant height at the three locations in both years. While, among the lines, AC 313-293 and Local 35 performed second best. Other lines; 2QQ $17^{4}$, S 72-78-10 and G 45-2 performed third best for the three locations (Tables 2 and 3).

\subsubsection{Basal Diameter}

In 2010 and 2011, Ife Ken DI 400 and Ife Ken 400 had highest basal diameter compared to other improved varieties at the three locations. However, their mean values were not significantly higher than other improved varieties; Tainung-1, Cuba 108 and Ife Ken 100 and line; AC 313-293. Local 35 gave significant lowest values for the three locations (Tables 2 and 3). 


\subsubsection{Fiber Yield}

Among the improved varieties, Ife Ken DI 400 gave the highest fiber yield at the three locations in 2010 and 2011, but it was not significantly higher than another improved variety Ife Ken 400. Improved varieties Cuba 108 and Ife Ken 100 and line G 45-2 performed second best, while, improved variety Tainung -1 and lines 2 QQ $17^{4}$ and S 72-78-10 performed third best. Local 35 had the least values at the three locations (Tables 2 and 3).

\subsubsection{Core Yield}

In both years, improved varieties Ife Ken DI 400, Ife Ken 400 and Cuba 108 had a significantly highest core yield at the three locations. Lines AC 313-293, 2QQ $17^{4}$ and S 72-78-10 and improved variety Tainung-1 performed second best, while, line G $45-2$ and local 35 had significant lowest values at the three locations (Tables 2 and 3).

\subsection{Combined Analysis of Variance and Mean Values for the Three Locations and Years}

\subsubsection{Analysis of Variance}

Across three locations and different years, combined analysis of variance was carried out. The results were shown in Table 4. There were significant $(\mathrm{P}<0.05)$ differences among the cultivars, locations, cultivar $\mathrm{x}$ year and year $\mathrm{x}$ location interactions for the traits. Influence of year and cultivar $\mathrm{x}$ location and cultivar $\mathrm{x}$ location $\mathrm{x}$ year were not significant (Table 4). There were significant differences in plant height, basal diameter, fiber yield and core yield among the cultivars, significant differences among locations in fiber yield and core yield and there were significant cultivar $\mathrm{x}$ year and year $\mathrm{x}$ location interactions for fiber yield and core yield (Table 4). This indicated that the performances of the cultivars for fiber yield and core yield were significantly affected by different locations and years.

\subsubsection{Mean Values}

Improved varieties Ife Ken DI 400 and Ife Ken 400 gave the highest plant height values $(278.6$ and $275.4 \mathrm{~cm})$ respectively in a combined two years analysis, they were significantly better than other improved varieties, lines and local (Table 5). Improved varieties Ife Ken DI 400 and Tainung-1 gave the highest basal diameter values (2.6 and $2.4 \mathrm{~cm}$ ) respectively in combined two years analysis. They were not significantly different from improved varieties Ife Ken 400 and Ife Ken 100 and lines G 45-2 and AC 313-293. The least value $(1.4 \mathrm{~cm})$ was given by Local 35 (Table 5). Improved variety Ife ken DI 400 gave the significantly highest value $(2848.1 \mathrm{~kg} / \mathrm{ha})$ for fiber yield in a combined analysis, this was followed by the second best; improved varieties Ife Ken 400, Tainung-1 and Cuba 108 while the lowest value (1105 kg/ha) was recorded for Local 35 (Table 5). Improved variety Ife Ken DI 400 gave the highest core yield value $(4331.2 \mathrm{~kg} / \mathrm{ha})$ in a combined analysis, but the yield was not significantly higher than value $(4264.7 \mathrm{~kg} / \mathrm{ha}$ ) recorded for another improved variety Cuba 108 . The lowest value $(2348 \mathrm{~kg} / \mathrm{ha}$ ) was given by Local 35 (Table 5). The highest fiber yield and core yield of the improved variety Ife Ken 400 could be attributed to its highest performances for plant height and basal diameter across the locations.

\subsection{Stability Analysis}

In Shukla's (1972) stability variance procedure, the stable genotype has the lowest stability variance $(\sigma 2 i)$ value. The most stable cultivars in fiber yield and core yield were the improved varieties. For the fiber yield and core yield the most stable variety among the improved varieties was Ife Ken DI 400, followed by Ife Ken 400 and Ife Ken 100, while the fourth ranked stabled cultivar was Cuba 108. However, the most unstable variety was Tainung-1 (Table 6). Among the lines, AC 313-293 was most stable; it ranked seventh, while G 45-2 was regarded as most unstable cultivar followed by Local 35 and 2QQ $17^{4}$ that ranked eighth, ninth and tenth respectively.

\subsection{Correlations Between Assessed Traits}

Correlations between four assessed traits for combined analysis were shown in Table 7. Significantly $(\mathrm{P}<0.05)$ positive correlation was observed between fiber yield and core yield, fiber yield and basal diameter, core yield and basal diameter, basal diameter and plant height. Positively significant correlation means these two traits would increase together. As an example, in this study, significant positive correlation was observed between fiber yield and core yield, it means when the fiber yield increased, the core yield also increased. Likewise, significant positive correlations were observed between fiber yield and basal diameter, core yield and basal diameter and basal diameter and plant height, it means when basal diameter increased, the fiber yield, core yield and plant height increased.

\section{Conclusions and Recommendations}

In this study, ten kenaf cultivars which consist of five improved varieties, four lines and one local were evaluated 
in three locations across two years. Genotype $\mathrm{x}$ environment interactions occurred for kenaf cultivars planted in different environments. The cultivars performed differently in the three environments. Among the improved varieties, newly developed Ife Ken DI (daylenght insensitive or daylenght neutral) recorded highest plant hieght, basal diameter, fiber yield and core yield in the three environments across the years. When compared the mean yields for the two measured yield characteristics in the combined analysis, newly developed improved Ife Ken DI 400 was the variety that tended to have the highest fiber yield and core yield in the two years and three locations among the five improved varieties in specific and ten cultivars in general.

The stability analysis was used to analyze the ten kenaf cultivars for fiber yield and core yield. Newly developed Ife Ken DI 400 was most in fiber yield and core yield and would therefore be the variety of choice for the three locations. Among the lines, AC 313-293 was most stable for fiber yield and core yield and would therefore be the line of choice for further breeding activities when desired yield traits are needed.

From this study, it is recommended that for kenaf production under three different agro-ecologies; high rain forest agro-ecology, transitional rain forest agro-ecology and derive savanna agro-ecology of Southwest Nigeria, newly developed improved and daylenght neutral kenaf variety Ife Ken DI 400 would be the best, this could be followed by Ife Ken 400 and Ife Ken 100 .

Table 1. Kenaf varieties used for G x E interaction and stability analysis

\begin{tabular}{|c|c|c|}
\hline Entry & Genotype & Origin \\
\hline \multicolumn{3}{|c|}{ Improved } \\
\hline 1 & Ife Ken DI 400 & IAR\&T Nigeria \\
\hline 2 & Ife Ken 400 & IAR\&T Nigeria \\
\hline 3 & Ife Ken DI 100 & IAR\&T Nigeria \\
\hline 4 & Tainung -1 & USA/Mexico \\
\hline 5 & Cuba 108 & Spain \\
\hline \multicolumn{3}{|c|}{ Lines } \\
\hline 6 & S $72-78-10$ & Unspecified \\
\hline 7 & G $45 \quad 2$ & Unspecified \\
\hline 8 & AC 313293 & Unspecified \\
\hline 9 & 2QQ $17^{4}$ & Unspecified \\
\hline \multicolumn{3}{|c|}{ Local } \\
\hline 10 & Local 35 & Nigeria \\
\hline
\end{tabular}

Table 2. Mean values for six traits of ten kenaf cultivars evaluated at three environments for the 2010 season

\begin{tabular}{ccccccccccccccc}
\hline \multirow{2}{*}{ Cultivar } & \multicolumn{3}{c}{ Plant Height $(\mathrm{cm})$} & \multicolumn{3}{c}{ Basal Diameter $(\mathrm{cm})$} & \multicolumn{2}{c}{ Fiber Yield (kg/ha) } & \multicolumn{3}{c}{ Core Yield (kg/ha) } \\
& Ikenne & Ibadan & Ilora & Ikenne & Ibadan & Ilora & Ikenne & Ibadan & Ilora & Ikenne & Ibadan & Ilora \\
\hline Ife Ken DI 400 & $278.2 \mathrm{a}$ & $274.2 \mathrm{a}$ & $277.2 \mathrm{a}$ & $2.6 \mathrm{a}$ & $2.4 \mathrm{a}$ & $2.6 \mathrm{a}$ & $2816.3 \mathrm{a}$ & $2856.3 \mathrm{a}$ & $2986.8 \mathrm{a}$ & $4429.1 \mathrm{a}$ & $4426.3 \mathrm{a}$ & $4549.1 \mathrm{a}$ \\
AC 313 293 & $162.7 \mathrm{~b}$ & $193.2 \mathrm{~b}$ & $198.5 \mathrm{~b}$ & $2.1 \mathrm{ab}$ & $2.1 \mathrm{ab}$ & $2.3 \mathrm{ab}$ & $1142.5 \mathrm{~d}$ & $1176.2 \mathrm{~d}$ & $1396.4 \mathrm{~d}$ & $3742.8 \mathrm{~b}$ & $3246.2 \mathrm{~b}$ & $3764.5 \mathrm{~b}$ \\
2QQ 17 & $125.4 \mathrm{c}$ & $178.5 \mathrm{c}$ & $182.1 \mathrm{c}$ & $1.7 \mathrm{~b}$ & $1.8 \mathrm{~b}$ & $1.7 \mathrm{~b}$ & $1345.1 \mathrm{c}$ & $1387.3 \mathrm{c}$ & $1467.1 \mathrm{c}$ & $3136.4 \mathrm{~b}$ & $3037.3 \mathrm{~b}$ & $3429.2 \mathrm{~b}$ \\
Ife Ken 400 & $266.8 \mathrm{a}$ & $288.9 \mathrm{a}$ & $292.2 \mathrm{a}$ & $2.4 \mathrm{a}$ & $2.6 \mathrm{a}$ & $2.6 \mathrm{a}$ & $2207.7 \mathrm{a}$ & $2242.7 \mathrm{a}$ & $2522.4 \mathrm{a}$ & $4123.8 \mathrm{a}$ & $4229.3 \mathrm{a}$ & $4654.7 \mathrm{a}$ \\
Tainung - 1 & $253.3 \mathrm{a}$ & $263.6 \mathrm{a}$ & $267.8 \mathrm{a}$ & $2.1 \mathrm{ab}$ & $2.0 \mathrm{ab}$ & $2.1 \mathrm{ab}$ & $1445.6 \mathrm{c}$ & $1473.7 \mathrm{c}$ & $1663.9 \mathrm{c}$ & $3336.6 \mathrm{~b}$ & $3533.7 \mathrm{~b}$ & $3822.3 \mathrm{~b}$ \\
S 72-78-10 & $137.6 \mathrm{c}$ & $174.1 \mathrm{c}$ & $179.3 \mathrm{c}$ & $1.7 \mathrm{~b}$ & $1.8 \mathrm{~b}$ & $1.8 \mathrm{~b}$ & $1443.9 \mathrm{c}$ & $1474.7 \mathrm{c}$ & $1834.2 \mathrm{c}$ & $3213.3 \mathrm{~b}$ & $3114.7 \mathrm{~b}$ & $3531.8 \mathrm{~b}$ \\
Cuba 108 & $273.8 \mathrm{a}$ & $247.3 \mathrm{a}$ & $252.7 \mathrm{a}$ & $2.2 \mathrm{ab}$ & $2.1 \mathrm{ab}$ & $2.1 \mathrm{ab}$ & $1771.5 \mathrm{~b}$ & $1805.3 \mathrm{~b}$ & $1925.9 \mathrm{~b}$ & $4246.9 \mathrm{a}$ & $4045.3 \mathrm{a}$ & $4758.8 \mathrm{a}$ \\
G 45 2 & $132.2 \mathrm{c}$ & $190.6 \mathrm{c}$ & $194.2 \mathrm{c}$ & $2.2 \mathrm{ab}$ & $2.2 \mathrm{ab}$ & $2.2 \mathrm{ab}$ & $1562.1 \mathrm{~b}$ & $1609.3 \mathrm{~b}$ & $1789.4 \mathrm{~b}$ & $2563.8 \mathrm{c}$ & $2469.3 \mathrm{c}$ & $2273.1 \mathrm{c}$ \\
Ife Ken 100 & $285.9 \mathrm{a}$ & $252.8 \mathrm{a}$ & $257.4 \mathrm{a}$ & $2.2 \mathrm{ab}$ & $2.2 \mathrm{ab}$ & $2.2 \mathrm{ab}$ & $1838.3 \mathrm{~b}$ & $1769.3 \mathrm{~b}$ & $1859.6 \mathrm{~b}$ & $3376.3 \mathrm{~b}$ & $3772.7 \mathrm{~b}$ & $3655.9 \mathrm{~b}$ \\
Local 35 & $222.3 \mathrm{~b}$ & $229.5 \mathrm{~b}$ & $233.1 \mathrm{~b}$ & $1.4 \mathrm{c}$ & $1.4 \mathrm{c}$ & $1.4 \mathrm{c}$ & $1159.9 \mathrm{e}$ & $1023.9 \mathrm{e}$ & $1173.2 \mathrm{e}$ & $2713.7 \mathrm{c}$ & $2218.9 \mathrm{c}$ & $2409.2 \mathrm{c}$ \\
Mean & $\mathbf{2 1 3 . 8}$ & $\mathbf{2 2 9 . 3}$ & $\mathbf{2 3 3 . 5}$ & $\mathbf{2 . 1}$ & $\mathbf{2 . 1}$ & $\mathbf{2 . 1}$ & $\mathbf{1 6 7 3 . 3}$ & $\mathbf{1 6 8 1 . 9}$ & $\mathbf{1 8 6 1 . 9}$ & $\mathbf{3 4 3 8 . 8}$ & $\mathbf{3 4 0 9 . 4}$ & $\mathbf{3 6 8 4 . 9}$ \\
\hline
\end{tabular}

Mean not followed with the same letter(s) on the same row are significantly different $(\mathrm{P}<0.05)$. 
Table 3. Mean values for six traits of ten kenaf cultivars evaluated at three environments for the 2011 season

\begin{tabular}{cccccccccccccccc}
\hline \multirow{2}{*}{ Cultivar } & \multicolumn{3}{c}{ Plant Height $(\mathrm{cm})$} & \multicolumn{3}{c}{ Basal Diameter $(\mathrm{cm})$} & \multicolumn{3}{c}{ Fiber Yield $(\mathrm{kg} / \mathrm{ha})$} & \multicolumn{3}{c}{ Core Yield (kg/ha) } \\
& Ikenne & Ibadan & Ilora & Ikenne & Ibadan & Ilora & Ikenne & Ibadan & Ilora & Ikenne & Ibadan & Ilora \\
\hline Ife Ken DI 400 & $284.2 \mathrm{a}$ & $265.7 \mathrm{a}$ & $291.4 \mathrm{a}$ & $2.4 \mathrm{a}$ & $2.7 \mathrm{a}$ & $2.8 \mathrm{a}$ & $2856.3 \mathrm{a}$ & $2756.3 \mathrm{a}$ & $2816.3 \mathrm{a}$ & $4426.3 \mathrm{a}$ & $4026.1 \mathrm{a}$ & $4129.8 \mathrm{a}$ \\
AC 313 293 & $193.2 \mathrm{~b}$ & $184.8 \mathrm{~b}$ & $142.3 \mathrm{~b}$ & $2.1 \mathrm{ab}$ & $2.5 \mathrm{ab}$ & $2.3 \mathrm{ab}$ & $1176.2 \mathrm{~d}$ & $1079.5 \mathrm{~d}$ & $1142.5 \mathrm{~d}$ & $3246.2 \mathrm{~b}$ & $3446.6 \mathrm{~b}$ & $3542.3 \mathrm{~b}$ \\
2QQ 17 & $178.5 \mathrm{c}$ & $168.3 \mathrm{c}$ & $115.1 \mathrm{c}$ & $1.8 \mathrm{~b}$ & $1.3 \mathrm{~b}$ & $1.2 \mathrm{~b}$ & $1387.3 \mathrm{c}$ & $1280.1 \mathrm{c}$ & $1345.1 \mathrm{c}$ & $3037.3 \mathrm{~b}$ & $3237.1 \mathrm{~b}$ & $3336.7 \mathrm{~b}$ \\
Ife Ken 400 & $268.9 \mathrm{a}$ & $279.1 \mathrm{a}$ & $256.4 \mathrm{a}$ & $2.6 \mathrm{a}$ & $2.9 \mathrm{a}$ & $2.6 \mathrm{a}$ & $2242.7 \mathrm{a}$ & $2145.7 \mathrm{a}$ & $2207.7 \mathrm{a}$ & $4229.3 \mathrm{a}$ & $4129.8 \mathrm{a}$ & $4323.5 \mathrm{a}$ \\
Tainung-1 & $273.6 \mathrm{a}$ & $254.9 \mathrm{a}$ & $203.8 \mathrm{a}$ & $2.0 \mathrm{ab}$ & $2.1 \mathrm{ab}$ & $2.1 \mathrm{ab}$ & $1473.7 \mathrm{c}$ & $1378.6 \mathrm{c}$ & $1445.6 \mathrm{c}$ & $3533.7 \mathrm{~b}$ & $3133.3 \mathrm{~b}$ & $3536.2 \mathrm{~b}$ \\
S 72-78-10 & $164.1 \mathrm{c}$ & $165.0 \mathrm{c}$ & $127.3 \mathrm{c}$ & $1.8 \mathrm{~b}$ & $1.7 \mathrm{~b}$ & $1.7 \mathrm{~b}$ & $1474.4 \mathrm{c}$ & $1379.9 \mathrm{c}$ & $1443.9 \mathrm{c}$ & $3114.7 \mathrm{~b}$ & $3714.1 \mathrm{~b}$ & $3013.6 \mathrm{~b}$ \\
Cuba 108 & $237.3 \mathrm{a}$ & $238.8 \mathrm{a}$ & $263.5 \mathrm{a}$ & $2.1 \mathrm{ab}$ & $2.2 \mathrm{ab}$ & $2.2 \mathrm{ab}$ & $1805.3 \mathrm{~b}$ & $1709.5 \mathrm{~b}$ & $1771.5 \mathrm{~b}$ & $4045.3 \mathrm{a}$ & $4145.4 \mathrm{a}$ & $4346.3 \mathrm{a}$ \\
G 45-2 & $160.6 \mathrm{c}$ & $181.2 \mathrm{c}$ & $152.4 \mathrm{c}$ & $2.2 \mathrm{ab}$ & $2.2 \mathrm{ab}$ & $2.2 \mathrm{ab}$ & $1609.3 \mathrm{~b}$ & $1504.1 \mathrm{~b}$ & $1562.1 \mathrm{~b}$ & $2469.3 \mathrm{c}$ & $2269.1 \mathrm{c}$ & $2363.8 \mathrm{c}$ \\
Ife Ken DI 100 & $262.8 \mathrm{a}$ & $252.8 \mathrm{a}$ & $275.6 \mathrm{a}$ & $2.2 \mathrm{ab}$ & $2.2 \mathrm{ab}$ & $2.2 \mathrm{ab}$ & $1769.3 \mathrm{~b}$ & $1769.3 \mathrm{~b}$ & $1838.3 \mathrm{~b}$ & $3772.7 \mathrm{~b}$ & $3782.7 \mathrm{~b}$ & $3676.4 \mathrm{~b}$ \\
Local 35 & $219.5 \mathrm{~b}$ & $229.5 \mathrm{~b}$ & $212.8 \mathrm{~b}$ & $1.4 \mathrm{c}$ & $1.4 \mathrm{c}$ & $1.4 \mathrm{c}$ & $1023.9 \mathrm{e}$ & $1093.9 \mathrm{e}$ & $1159.9 \mathrm{e}$ & $2218.9 \mathrm{c}$ & $2218.9 \mathrm{c}$ & $2313.2 \mathrm{c}$ \\
Mean & $\mathbf{2 2 4 . 3}$ & $\mathbf{2 2 2 . 1}$ & $\mathbf{2 0 4 . 1}$ & $\mathbf{2 . 1}$ & $\mathbf{2 . 1}$ & $\mathbf{2 . 1}$ & $\mathbf{1 6 8 1 . 8}$ & $\mathbf{1 6 0 9 . 7}$ & $\mathbf{1 6 7 3 . 3}$ & $\mathbf{3 4 0 9 . 4}$ & $\mathbf{3 4 1 0 . 3}$ & $\mathbf{3 4 5 8 . 2}$ \\
\hline
\end{tabular}

Mean not followed with the same letter(s) on the same row are significantly different $(\mathrm{P}<0.05)$.

Table 4. Mean squares for various characteristics for ten kenaf cultivars across localities and years

\begin{tabular}{cccccc}
\hline Sources of variation & DF & Plant Height $(\mathrm{cm})$ & $\begin{array}{c}\text { Basal Diameter } \\
(\mathrm{cm})\end{array}$ & $\begin{array}{c}\text { Fiber Yield } \\
(\mathrm{kg} / \mathrm{ha})\end{array}$ & Core Yield (kg/ha) \\
\hline Cultivar & 9 & $537.267^{* *}$ & $125.448^{* *}$ & $14.931^{* *}$ & $405.358^{* *}$ \\
Location & 2 & 17456.302 & 16387.046 & $2499.667^{* *}$ & $19355.302^{* *}$ \\
Year & 1 & 62957.045 & 38476.557 & 1996.005 & 60883.095 \\
Cultivar x Loc. & 18 & 543.477 & 265.332 & 43.615 & 412.500 \\
Cultivar x Year & 9 & 2453.023 & 586.432 & $86.897^{* *}$ & $1165.010^{* *}$ \\
Year x Location & 2 & 1636.402 & 136.399 & $264.984^{* *}$ & $1828.703^{* *}$ \\
Cultivar x Loc. x Year & 18 & 167.443 & 46.357 & 25.449 & 146.454 \\
\hline
\end{tabular}

** Significant at $\mathrm{P}<0.05$.

Table 5. Means of the different traits for ten kenaf cultivars across locations and years

\begin{tabular}{ccccc}
\hline Cultivars & Plant Height $(\mathrm{cm})$ & Basal Diameter $(\mathrm{cm})$ & Fiber Yield (Kg/ha) & Core Yield $(\mathrm{Kg} / \mathrm{ha})$ \\
\hline Ife Ken DI 400 & $278.6 \mathrm{a}$ & $2.6 \mathrm{a}$ & $2848.1 \mathrm{a}$ & $4331.2 \mathrm{a}$ \\
AC 313-293 & $228.9 \mathrm{c}$ & $2.3 \mathrm{ab}$ & $1807.4 \mathrm{~b}$ & $3498.1 \mathrm{~b}$ \\
2QQ $17^{4}$ & $157.9 \mathrm{~d}$ & $1.6 \mathrm{~b}$ & $1368.7 \mathrm{c}$ & $3202.3 \mathrm{~b}$ \\
Ife Ken 400 & $275.4 \mathrm{a}$ & $2.0 \mathrm{ab}$ & $1830.9 \mathrm{~b}$ & $3892.5 \mathrm{~b}$ \\
Tainung-1 & $252.9 \mathrm{~b}$ & $2.4 \mathrm{a}$ & $1863.2 \mathrm{~b}$ & $3482.7 \mathrm{~b}$ \\
S 72-78-10 & $157.9 \mathrm{~d}$ & $1.9 \mathrm{~b}$ & $1508.5 \mathrm{c}$ & $3283.8 \mathrm{~b}$ \\
Cuba 108 & $252.8 \mathrm{~b}$ & $1.9 \mathrm{~b}$ & $1798.2 \mathrm{~b}$ & $4264.7 \mathrm{a}$ \\
G 45-2 & $166.7 \mathrm{~d}$ & $2.2 \mathrm{ab}$ & $1606.1 \mathrm{bc}$ & $2401.4 \mathrm{~d}$ \\
Ife Ken 100 & $264.6 \mathrm{~b}$ & $2.2 \mathrm{ab}$ & $1185.6 \mathrm{~d}$ & $3671.1 \mathrm{~b}$ \\
Local 35 & $227.8 \mathrm{c}$ & $1.4 \mathrm{c}$ & $1105.9 \mathrm{e}$ & $2348.8 \mathrm{~d}$
\end{tabular}

Mean not followed with the same letter(s) on the same row are significantly different $(\mathrm{P}<0.05)$. 
Table 6. shukla's stability variance values and ranks for ten kenaf cultivars evaluated in 2010 and 2011 seasons

\begin{tabular}{cccccc}
\hline \multirow{2}{*}{ Cultivar } & \multicolumn{2}{c}{ Fiber yield (t/ha) } & & \multicolumn{2}{c}{ Core yield (t/ha) } \\
\cline { 2 - 3 } \cline { 5 - 6 } & Stability variance & Rank & & Stability variance & Rank \\
\hline Ife Ken DI 400 & 123.4 & 1 & & 205.2 & 1 \\
AC 313 293 & 645.2 & 6 & & 834.6 & 6 \\
2QQ 17 & 832.6 & 9 & & 956.9 & 8 \\
Ife Ken 400 & 175.9 & 2 & & 234.7 & 2 \\
Tainung-1 & 386.2 & 5 & & 321.6 & 4 \\
S 72-78-10 & 693.5 & 7 & & 845.3 & 7 \\
Cuba 108 & 224.1 & 4 & & 376.8 & 5 \\
G 45-2 & 725.5 & 8 & & 1265.8 & 10 \\
Ife Ken 100 & 185.2 & 3 & & 256.9 & 3 \\
Local 35 & 982.5 & 10 & 1143.7 & 9 \\
\hline
\end{tabular}

Table 7. Simple correlations among four traits of kenaf cultivars for the combined analysis

\begin{tabular}{llll}
\hline & Fiber yield & Core yield & Basal diameter \\
\hline Core yield & $0.934^{* *}$ & & \\
Basal diameter & $0.295^{* *}$ & $0.257^{* *}$ & \\
Plant height & 0.167 & 0.245 & $0.678^{* *}$
\end{tabular}

**Significant at $\mathrm{P}<0.05$.

\section{References}

Baker, R. J. (1988). Tests for cross-over genotype-environment interactions. Canadian Journal of Plant Sciences, 68, 405-410. http://dx.doi.org/10.4141/cjps88-051

Basford, K. E., \& Cooper, M. (1998). Genotype X environment interactions and some considerations of their implications for wheat breeding in Australia. Australian Journal of Agricultural Research, 49, 154-174. http://dx.doi.org/10.1071/A97035

Becker, H. C., \& Leon, J. (1988). Stability analysis in plant breeding. Plant Breeding, 101, 1-23. http://dx.doi.org/10.1111/j.1439-0523.1988.tb00261.x

Ceccarelli, S. (1989). Wide adaptation: How wide? Euphytica, 40, 197-205.

Charles, L. (2002). Trends in New Crops and New Use. ASHS Press, Alexandria, VA.

Cheng, Z. (2001). Kenaf research, products and applications in Japan (in Chinese). Plant Fibers and Products, 23(3), 16-24.

DeLacy, I. H., Cooper, M., \& Basford, K. E. (1996). Relationships among analytical methods used to study genotype-by-environment interactions and evaluation of their impact on response to selection. M. S. Kang \& Jr. H. G. Zobel (Eds.), Genotype-by-environment interaction (pp. 51-84). CRC press, Boca Raton, Florida.

Dempsey, J. M. (1975). Fiber crops. The University Presses of Florida, Gainesville.

Fehr, W. R. (1991). Principles of cultivar development theory and technique (pp. 247-260). IOWA State University, USA.

Fehr, W. R. (1991). Principles of cultivar development theory and technique (pp. 247-260). IOWA State University, USA.

Food and Agriculture Organization (FAO). (1998). FAO Production Yearbook Vol. 32.

Gauch, H. G., \& Zobel, R. W. (1997). Identifying mega-environments and targeting genotypes. Crop Science, 37(2), 311-326. http://dx.doi.org/10.2135/cropsci1997.0011183X003700020002x 
Jackson, P., Robertson, M., Cooper, M., \& Hammer, G. L. (1998). The role of physiological understanding in Plant Breeding: From a breeding perspective. Field Crops Research, 49, 11-37. http://dx.doi.org/10.1016/S0378-4290(96)01012-X

LeMahieu, P. J., Oplinger, E. S., \& Putnam, D. H. (2003). Kenaf. Alternative Field Crops Manual. Retrieved from http://www.corn.agronomy.wisc.edu/FISC/Alternatives/Kenaf.htm

Lin, C. S., Binns, M. R., \& Lefkovitch, L. P. (1986). Stability analysis: where do we stand? Crop Science, 26, 894-900. http://dx.doi.org/10.2135/cropsci1986.0011183X002600050012x

Nassar, R., \& Huehn, M. (1987). Studies on estimation of phenotypic stability: Tests significance for nonparametric measures of phenotypic stability. Biometrics, 43, 45-53. http://dx.doi.org/10.2307/2531947

Nel, M. M., Agenbag, G. A., \& Purchase, J. L. (1998). Sources of variation for yield, protein content and hectoliter mass of spring wheat cultivars of the Western and Southern Cape. S. Afr. J. Plant Soil, 15(2), 72-79.

Purchase, J. (1997). Parametric analysis to describe genotype $\mathrm{x}$ environment interaction and yield stability in winter wheat. $\mathrm{PhD}$ thesis, University of the Free State, South Africa.

Romagosa, I., \& Fox, P. N. (1993). Genotype x environment interaction and adaptation. In M. D. Hayward, N. O. Bosemark, \& I. Romagosa (Eds.), Plant breeding: Principles and prospects (pp. 373-390). Chapman and Hall, London.

Shukla, G. K. (1972). Some statistical aspects of partitioning genotype-environmental components of variability. Heredity, 29, 237-245.

\section{Copyrights}

Copyright for this article is retained by the author(s), with first publication rights granted to the journal.

This is an open-access article distributed under the terms and conditions of the Creative Commons Attribution license (http://creativecommons.org/licenses/by/3.0/). 